\title{
EHMTI-0036. Gammacore device for treatment of migraine attack: preliminary report
}

\author{
L Grazzi , S Usai, G Bussone \\ From 4th European Headache and Migraine Trust International Congress: EHMTIC 2014 \\ Copenhagen, Denmark. 18-21 September 2014
}

\section{Introduction}

Despite the several options for treatment of migraine attack, sometimes pain episodes remain unresolved and often patients ask for non pharmacological methods for aborting attack which can be a valid alternative to the use of medications.

\section{Aim}

The application of a simple and non invasive VNS device (gammacore) for treatment of migraine attack .

\section{Method}

Thirthy patients, aged 18-65, suffering from migraine without aura according with HIS criteria, (5-9 attacks per month), were included in this open-label, single arm, multiple attack study.

Patients, after a specific educational training, treated from 3 to 6 migraine episodes by the portable VNS device. Treatment consisted of one, 90 seconds doses delivered to the right cervical branch of the vagus nerve.

\section{Results}

Ninety six migraine attacks were treated globally by a single shot application.

Ninety six attack were treated: 43 attacks were resolved completely within 30 minutes (44.8\%); for 42 (43.7\%) attacks the application did not show any benefit in the first 2 hours so patients recurred to rescue medication; in $11(11.4 \%)$ attacks the result was uncertain: no resolution of attack, only a moderate relief of pain.

No adverse events were recorded.

Headache Center, Neurological Institute C. Besta, Milano, Italy

\section{Conclusions}

The results suggest that VNS may be an effective and well tolerated treatment for migraine attack in a good percentage of cases, with one shot modality.

Randomized controlled studies are needed also to fix up the adequate dosage to apply the device for the resolution of pain.

No conflict of interest.

Published: 18 September 2014

doi:10.1186/1129-2377-15-S1-G12

Cite this article as: Grazzi et al:: EHMTI-0036. Gammacore device for

treatment of migraine attack: preliminary report. The Journal of

Headache and Pain 2014 15(Suppl 1):G12.

\section{SpringerOpen $^{\odot}$}

C 2014 Grazzi et al; licensee Springer. This is an Open Access article distributed under the terms of the Creative Commons Attribution License (http://creativecommons.org/licenses/by/2.0), which permits unrestricted use, distribution, and reproduction in any medium, provided the original work is properly cited.
Submit your manuscript to a SpringerOpen ${ }^{\circ}$ journal and benefit from:

- Convenient online submission

- Rigorous peer review

- Immediate publication on acceptance

- Open access: articles freely available online

- High visibility within the field

- Retaining the copyright to your article

Submit your next manuscript at $>$ springeropen.com 